\title{
Effects of diet quality on urea fates in sheep as assessed by refined, non-invasive $\left[{ }^{15} \mathrm{~N}^{15} \mathrm{~N}\right]$ urea kinetics
}

\author{
G. E. Lobley ${ }^{1 *}$, D. M. Bremner ${ }^{1}$ and G. Zuur ${ }^{2}$ \\ ${ }^{1}$ Rowett Research Institute, Bucksburn, Aberdeen AB21 9SB, UK \\ ${ }^{2}$ Biomathematics and Statistics Scotland, Rowett Research Institute, Bucksburn, Aberdeen AB21 9SB, UK
}

(Received 13 September 1999 - Revised 17 January 2000 - Accepted 15 February 2000)

\begin{abstract}
The effect of diet quality on urea production, entry into the gastrointestinal tract (GIT) and subsequent diversion to anabolic or catabolic fates was examined in four sheep (mean live weight $49.5 \mathrm{~kg}$ ). The animals received, in a crossover design, each of two rations, hay-grass pellets (1:1 HG) and a mixed concentrate-forage $(\mathrm{CF})$. Measurements were made of $\mathrm{N}$ balance and urea kinetics based on a $4 \mathrm{~d}$ continuous intravascular infusion of $\left[{ }^{15} \mathrm{~N}^{15} \mathrm{~N}\right]$ urea. Enrichments of $\left[{ }^{15} \mathrm{~N}^{15} \mathrm{~N}\right]$ - and $\left[{ }^{14} \mathrm{~N}^{15} \mathrm{~N}\right]$ urea in the urine, and faecal ${ }^{15} \mathrm{~N}$ content were determined each day. After $24 \mathrm{~h}$ of infusion, urinary $\left[{ }^{15} \mathrm{~N}^{15} \mathrm{~N}\right]$ urea enrichments reached constant enrichment but a further $24 \mathrm{~h}$ was required before $\left[{ }^{14} \mathrm{~N}^{15} \mathrm{~N}\right]$ urea enrichment was at plateau. The latter is derived from hydrolysis of urea to ${ }^{15} \mathrm{NH}_{3}$ in the digestive tract with subsequent absorption and reconversion to urea. The diets were not isonitrogenous (14.3 v. 17.1 g N supplied daily for HG and $\mathrm{CF}$ respectively) but showed no difference in $\mathrm{N}$ balance. Urea-N production was much greater $(16 \cdot 3 v .11 .1 \mathrm{~g} / \mathrm{d} ; P=0 \cdot 011)$ for CF compared with $\mathrm{HG}$ and more urea-N entered the GIT $(9.9 v .7 .7 ; P=0.07)$. A larger proportion of GIT entry was returned to ureagenesis (51 $v$. $42 \% ; P=0.047)$ for the CF diet but a smaller fraction was lost in the faeces $(3.3 \%$ v. $7.1 \%$; $P=0 \cdot 013$ ). In consequence, most of the additional urea-N which entered the GIT on the CF diet was returned to the ornithine cycle (probably as $\mathrm{NH}_{3}$ ) and the absolute amount available for anabolic purposes was similar between the rations $(3.9 v .4 .5 \mathrm{~g} \mathrm{~N} / \mathrm{d})$.
\end{abstract}

Urea: ${ }^{15} \mathrm{~N}$ kinetics: Gastrointestinal tract: Sheep

In most mammals, more urea is synthesised than is eliminated in the urine. This is because a variable proportion enters the gastrointestinal tract (GIT; Harmeyer \& Martens, 1980; Jackson et al. 1984) where hydrolysis to $\mathrm{NH}_{3}$ occurs, through the action of intestinal microflora. The liberated $\mathrm{NH}_{3}$ can then be absorbed and reconverted to urea or used as a precursor for bacterial protein synthesis. The latter process provides a route whereby urea-N, originating from hepatic detoxification of $\mathrm{NH}_{3}$ and catabolism of amino acids, can be 'salvaged' and re-utilised for productive purposes. This occurs for all species, including man (Jackson et al. 1993), but is of particular importance to ruminants, where the rumen microbes convert substantial quantities of urea-N into bacterial protein, which is subsequently digested and absorbed via the small intestine.

It has proved difficult, however, to determine how much of the urea-N which enters the GIT is returned to the animal in anabolic form. Most studies on urea-N kinetics have focussed on quantification of GIT entry, as either the difference between urea production and urinary urea elimination (e.g. Harmeyer \& Martens, 1980; Bunting et al. 1987) or from arterio-venous determinations across the digestive tract (e.g. Reynolds et al. 1991; Whitt et al. 1996; Lobley et al. 1998). Measurement of the amount returned for anabolism has required complex ${ }^{15} \mathrm{~N}$ kinetics (Siddons et al. 1985). A simpler tracer approach, based on isotopomer analysis of parent $\left[{ }^{15} \mathrm{~N}^{15} \mathrm{~N}\right]$ urea and daughter $\left[{ }^{14} \mathrm{~N}^{15} \mathrm{~N}\right]$ urea (derived from urea-N converted to $\mathrm{NH}_{3}$ in the GIT and returned to the ornithine cycle), has been used successfully in a range of studies on human subjects (Jackson et al. 1984, 1993) and non-ruminants (Wolfe, 1981). This approach was recently refined and applied to ruminants where, across varied levels of intake, a constant proportion (0.4) of GIT entry of urea-N was returned to the ornithine cycle, with the majority of the remainder probably available for anabolic purposes (Sarraseca et al.

\footnotetext{
Abbreviations: CF, concentrate-forage diet; GER, gastrointestinal entry rate; GIT, gastrointestinal tract; HG, hay-grass pellet diet; ROC, re-entry to ornithine cycle; UER, urea-N entry rate; UFE, urea-N to faecal excretion; UUA, urea-N utilised for anabolism; UUE, urinary urea-N elimination.

* Corresponding author: Dr Gerald E. Lobley, fax +44 12247166 29, email gel@rri.sari.ac.uk
} 
1998). Although the fractional transfers were unaltered by intake level the absolute movements did change. These observations were with a single diet type and studies in dairy cows have reported the fraction of bacterial protein derived from endogenous urea-N varies between high-grain and high-forage rations (Al-Dehneh et al. 1997). Furthermore, certain technical concerns remained, notably whether the kinetics of isotope infusion were optimised and how much of the urea- $\mathrm{N}$ was excreted in faeces. The current study investigates urea kinetics across a further two diets and defines the time-courses of the various transfers.

\section{Materials and methods}

\section{Animals and diets}

Four Suffolk cross young wether sheep (range 43-55 kg live weight; mean $49.5 \mathrm{~kg}$ ) were examined on each of two diets: a mixed concentrate-forage (CF; g/kg: barley 300 , hay 500, molasses 100, fish meal 90, salts and vitamins 10; $830 \mathrm{~g} \mathrm{DM} / \mathrm{kg} ; 21.5 \mathrm{~g} \mathrm{~N} / \mathrm{kg} \mathrm{DM}$; estimated metabolisable energy $11.0 \mathrm{MJ} / \mathrm{kg} \mathrm{DM}$ ) and a 1:1 mixture (HG) of grass pellets (960 g DM/kg; 22.5 g N/kg DM; estimated metabolisable energy $10.5 \mathrm{MJ} / \mathrm{kg} \mathrm{DM}$ ) and dried chopped hay $(870 \mathrm{~g} \mathrm{DM} / \mathrm{kg} ; 9.0 \mathrm{~g} \mathrm{~N} / \mathrm{kg} \mathrm{DM}$; estimated metabolisable energy $7.9 \mathrm{MJ} / \mathrm{kg} \mathrm{DM}$ ). Diets were tested according to a balanced crossover design with at least $14 \mathrm{~d}$ of adjustment between diets. Throughout the whole trial each ration was offered as $1000 \mathrm{~g} / \mathrm{d}$, as fed. This was supplied as 24-hourly portions from automated feeders for the last $10 \mathrm{~d}$ of each period when the animals were maintained in metabolism crates. During the time in the crates the sheep were harnessed for collection of urine by suction and faeces by bag, with total collections of excreta made daily for the last $4 \mathrm{~d}$ on the diet. Urine was aspirated into plastic bottles containing $100 \mathrm{ml} 4 \mathrm{M}-\mathrm{HCl}$. Subsamples of urine and faeces collected daily were taken for chemical and isotopic analyses, with a combined sample (based on $10 \%$ of urine weight and $50 \%$ of faecal weight) used for determination of overall $\mathrm{N}$ balance. Urine and faecal samples were stored at $4^{\circ} \mathrm{C}$ during the $4 \mathrm{~d}$ of collection and then at $-20^{\circ} \mathrm{C}$ until analysed. Just prior to the $\mathrm{N}$ balance, samples of urine and faeces were taken for measurement of ${ }^{15} \mathrm{~N}$ natural abundances. The $\mathrm{N}$ content of urine and faeces were measured as described previously (Sarreseca et al. 1998), as was the concentration of urea in the daily samples of both urine and plasma.

\section{Isotope infusions and analyses}

Animals were prepared with a temporary catheter in each jugular vein at least $2 \mathrm{~d}$ before commencement of the $\mathrm{N}$ balance measurements. Isotope infusion conditions were similar to those described previously (Sarraseca et al. 1998), except that intravascular infusions of $\left[{ }^{15} \mathrm{~N}^{15} \mathrm{~N}\right]$ urea$\mathrm{N}$ were continued for $4 \mathrm{~d}$ (the same period as the $\mathrm{N}$ balance) at rates $(1.2 \mathrm{mmol} \mathrm{N} / \mathrm{d})$ calculated to increase $\left[{ }^{15} \mathrm{~N}^{15} \mathrm{~N}\right]$ urea-N enrichments in urine by approximately 0.15-0.25 atom percent excess at 'plateau'. Analyses for the proportions of $\left[{ }^{15} \mathrm{~N}^{15} \mathrm{~N}\right],\left[{ }^{14} \mathrm{~N}^{15} \mathrm{~N}\right]$ and $\left[{ }^{14} \mathrm{~N}^{14} \mathrm{~N}\right]$ in urinary urea were by isotope-ratio $\mathrm{MS}$ as described previously (Sarreseca et al. 1998), with the same care taken to allow for $\left[{ }^{14} \mathrm{~N}^{15} \mathrm{~N}\right]$ urea both present in the infusate and produced by non-monomolecular reactions during hypobromite release of $\mathrm{N}_{2}$ gas. Without correction for the latter, $\left[{ }^{15} \mathrm{~N}^{15} \mathrm{~N}\right]$ urea is underestimated and $\left[{ }^{14} \mathrm{~N}^{15} \mathrm{~N}\right]$ urea overestimated. The correction was usually 4-6\% of $\left[{ }^{15} \mathrm{~N}^{15} \mathrm{~N}\right]$ urea enrichment. The ${ }^{15} \mathrm{~N}$ content in freeze-dried faeces was determined on triplicate samples $(10 \mathrm{mg})$ by combustion to $\mathrm{N}_{2}$ in an elemental analyser and continuous flow isotope-ratio MS (Sarreseca et al. 1998). Enrichment data for the urea species and faecal-N were quantified as $\left[{ }^{15} \mathrm{~N}\right] /$ total $\mathrm{N}$ and corrected for the value in background (natural abundance) samples.

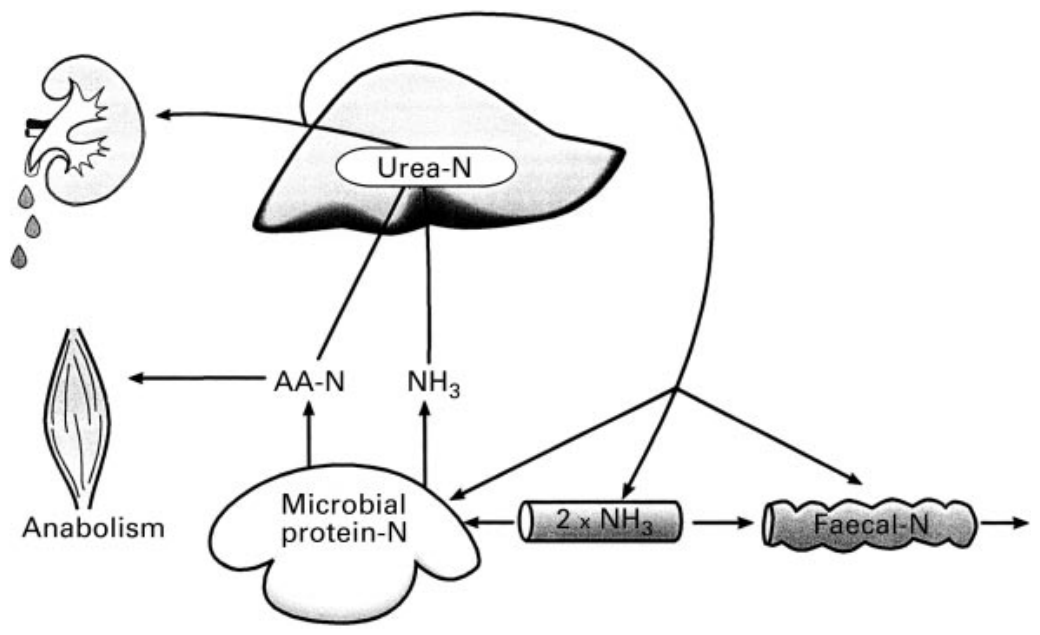

Fig. 1. Schematic diagram of urea-N fates within the body. Urea, synthesised mainly within the liver, can either be eliminated in urine or enter the digestive tract. In the latter, the action of microbial urease releases $\mathrm{NH}_{3}$ that can either be: (1) lost as part of the faecal-N; (2) absorbed and reconverted to urea; or (3) converted to microbial products, the amino acids of which can be absorbed and either converted to urea or used to support tissue anabolism. AA, amino acid. 


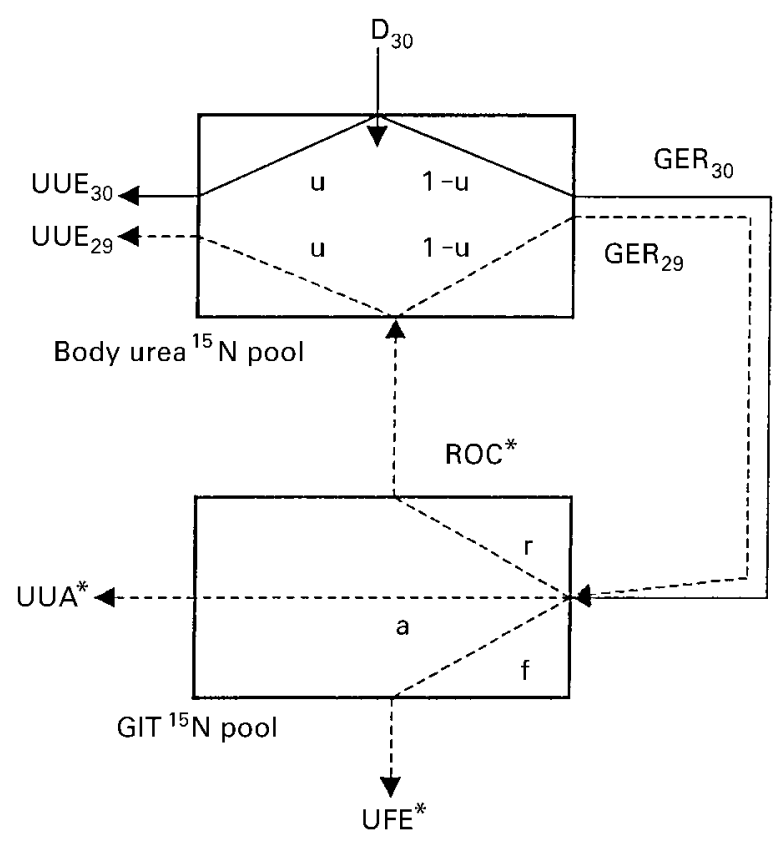

Fig. 2. Schematic two-pool model with isotope flows based on infusion (or injection) of $\left[{ }^{15} \mathrm{~N}^{15} \mathrm{~N}\right]$ urea. Fates of ${ }^{15} \mathrm{~N}$ direct from the dose are represented as (-) while fates from ${ }^{15} \mathrm{~N}$ liberated as $\mathrm{NH}_{3}$ in the gastrointestinal tract (GIT) are shown as (--). Movements of $\left[{ }^{15} \mathrm{~N}^{15} \mathrm{~N}\right]$ urea are given the subscript 30 while those of $\left[{ }^{14} \mathrm{~N}^{15} \mathrm{~N}\right]$ urea are given the subscript 29. D, dose; UUE, urinary urea-N elimination; GER, GIT entry rate; ROC*, return to ornithine cycle (mainly as ${ }^{15} \mathrm{NH}_{3}$ ); UUA* urea- ${ }^{15} \mathrm{~N}$ utilised for anabolism (mainly as bacterial protein); UFE* ${ }^{\star}$ urea- ${ }^{15} \mathrm{~N}$ to faecal excretion. Fraction transfers of GER to ROC*, UUA* and UFE* are represented by $r$, a and $f$ respectively while $u$ is the proportion of the dose eliminated in the urine.

\section{Model development}

The mass movements of urea between hepatic synthesis, urinary elimination, entry into the digestive tract and use for anabolic purposes are illustrated schematically in Fig. 1. The model (Fig. 2) based on the movements of ${ }^{15} \mathrm{~N}$ following [ $\left.{ }^{15} \mathrm{~N}^{15} \mathrm{~N}\right]$ urea infusion or injection, follows those described by Jackson et al. $(1984,1993)$ and Sarraseca et al. (1998). Urea synthesised (urea-N entry rate; UER) primarily in the liver can suffer two fates only: a fraction (u) is eliminated in the urine (urinary urea-N elimination; UUE), while the remainder $(1-\mathrm{u})$ enters the GIT (GIT entry rate; GER). The latter is hydrolysed in the lumen by bacterial action and the liberated $\mathrm{NH}_{3}$ may undergo several fates: (1) a portion (f) is excreted as $\mathrm{N}$ products in the faeces (urea-N to faecal excretion; UFE); (2) a portion (r) re-enters to the ornithine cycle (ROC), either directly as absorbed $\mathrm{NH}_{3}$ or indirectly from catabolism of products of microbial or mammalian $\mathrm{NH}_{3}$ metabolism; (3) while the remainder (a) undergoes anabolic use (urea-N utilised for anabolism; UUA) by the animal via microbial and mammalian metabolites of $\mathrm{NH}_{3}$.

The main equations used in this study are detailed later. The background and derivations of these equations are detailed in the Appendix. That section also includes the equations used when corrections are not employed at the analysis stage for the amount of $\left[{ }^{14} \mathrm{~N}^{15} \mathrm{~N}\right]$ urea present in the infusate. The section also includes discussion of the consequences of not employing a model based on multiple entry of urea into the GIT, plus correction of an error in the previous report (Sarraseca et al. 1998). All absolute doses and movements for this continuous infusion study are expressed as mass/time, both for faecal and urea measurements (for single dose experiments, the data would be expressed over the time of total collection of urine and faeces). The measured requirements are: (1) $\left[{ }^{15} \mathrm{~N}^{15} \mathrm{~N}\right]$ urea in the dose; (2) faecal $\mathrm{N}$ and ${ }^{15} \mathrm{~N}$ enrichment (atom percent excess); (3) total urine urea-N; (4) urinary $\left[{ }^{15} \mathrm{~N}^{15} \mathrm{~N}\right]$ and $\left[{ }^{14} \mathrm{~N}^{15} \mathrm{~N}\right]$ urea-N proportions (each as the mole fraction of labelled urea-N/total urea-N).

If the dose $\left(\mathrm{D}_{30}\right.$, mass/time $)$ of $\left[{ }^{15} \mathrm{~N}^{15} \mathrm{~N}\right]$ urea infused or injected is assumed to be pure (or adjusted for purity at the mass spectrometry analysis stage; see Sarreseca et al. 1998) and $\mathrm{UUE}_{30}$ and $\mathrm{UUE}_{29}$ represent $\left[{ }^{15} \mathrm{~N}^{15} \mathrm{~N}\right]$ and $\left[{ }^{14} \mathrm{~N}^{15} \mathrm{~N}\right]$ urea-N respectively in the urine at isotopic plateau, then:

$$
\mathrm{UER}=\left(\frac{\mathrm{E}_{\mathrm{D} 30}}{\mathrm{E}_{\mathrm{U} 30}}-1\right) \mathrm{D}_{30},
$$

where $\mathrm{E}_{\mathrm{D} 30}$ and $\mathrm{E}_{\mathrm{U} 30}$ are the enrichments of $\left[{ }^{15} \mathrm{~N}^{15} \mathrm{~N}\right]$ urea in the dose and urine respectively.

Then:

$$
\mathrm{u}=\frac{\mathrm{UUE}}{\mathrm{UER}},
$$

and

$$
\mathrm{r}=\frac{\rho}{(1-\mathrm{u})}
$$

where $\rho$ represents $\mathrm{UUE}_{29} /\left(\mathrm{UUE}_{29}+\mathrm{UUE}_{30}\right)$; this can be taken either from total urine urea-N as $\left[{ }^{14} \mathrm{~N}^{15} \mathrm{~N}\right]$ and $\left[{ }^{15} \mathrm{~N}^{15} \mathrm{~N}\right]$ or more simply, from the $\left[{ }^{14} \mathrm{~N}^{15} \mathrm{~N}\right]$ : $\left[\right.$ total $\left.{ }^{15} \mathrm{~N}\right]$ ratio in urine urea. Then,

$$
\mathrm{f}=\frac{\mathrm{uUFE}^{*}}{(1-\mathrm{u})\left(\mathrm{UUE}_{29}+\mathrm{UUE}_{30}\right)},
$$

where $\mathrm{UFE}^{*}$ is the amount of ${ }^{15} \mathrm{~N}$ mass/time excreted in the faeces. The fraction of GIT entry to anabolism (a) is obtained by difference:

$$
\mathrm{a}=1-\mathrm{r}-\mathrm{f},
$$

and

$$
\mathrm{GER}=\mathrm{UER}-\mathrm{UUE} .
$$

Multiplication of the fractions, $r$, $f$ and a by GER converts the data into mass/time units for ROC, UFE and UUA respectively.

Alternatively, ROC can also be calculated from:

$$
\mathrm{ROC}=\rho \mathrm{UER},
$$

while UER may also be derived as:

$$
\mathrm{UER}=\frac{\mathrm{D}_{30}}{\mathrm{UUE}_{30}} \mathrm{UUE},
$$

and this equation is preferred for single dose studies. 


\section{Statistical analysis}

For data obtained under 'plateau' conditions (day 2 onwards for $\left[{ }^{15} \mathrm{~N}^{15} \mathrm{~N}\right]$ urea and day 3 onwards for $\left[{ }^{14} \mathrm{~N}^{15} \mathrm{~N}\right]$ urea kinetics), the full design allowed for twoway ANOVA, with animals as blocks and both period and diet as factors, with 2 residual degrees of freedom. In practice, there was no effect of period and this could be removed allowing one-way ANOVA. For several comparisons, the animal effect was not significant but this was retained in the analysis because the main effect (diet) still attained $P<0.05$. The effect of day of infusion was analysed by ANOVA with sheep as blocks and diet $\times$ day as treatment. All analyses were performed by means of Genstat for Windows, Release 3.2 (Lawes Agricultural Trust, Rothamsted, Herts., UK). Statistical significance was assessed by convention, i.e. $P<0 \cdot 05$, but due to the small number of animals used, trends, or tendencies, were also considered at $P<0 \cdot 10$. $P$ values greater than $0 \cdot 10$ were considered non-significant.

\section{Results}

All sheep completed the trial. There were no refusals and as the diets were not isonitrogenous $\mathrm{N}$ intake on $\mathrm{CF}$ exceeded that on $\mathrm{HG}(P=0 \cdot 015$, Table 1$)$. There was a tendency for apparent $\mathrm{N}$ digested $(P=0 \cdot 070)$ to be greater with the $\mathrm{CF}$ ration. Despite the increased $\mathrm{N}$ available to the animals, there was no difference in $\mathrm{N}$ retention between the two diets (Table 1). This was due to more total $\mathrm{N}(2.3 \mathrm{~g} \mathrm{~N}$, $P=0 \cdot 075)$ in the urine when the sheep were offered the $\mathrm{CF}$ diet. This extra $\mathrm{N}$ was all as urea-N. There was no difference in the proportion of total urine- $\mathrm{N}$ contributed by urea- $\mathrm{N}$ between the diets (average 0.60).

\section{$\left[{ }^{15} N\right]$ urea kinetics}

For both diets, the enrichment of $\left[{ }^{15} \mathrm{~N}^{15} \mathrm{~N}\right]$ urea in the urine was constant by day 2 of infusion (Fig. 3). This collection encompassed $24-48 \mathrm{~h}$ of infusion and, thus, the urea enrichment must have reached plateau within $24 \mathrm{~h}$. In contrast, $\left[{ }^{14} \mathrm{~N}^{15} \mathrm{~N}\right]$ urea enrichments were not stable until at least day 3 of infusion, i.e $48 \mathrm{~h}$ and beyond of infusion (Fig. 3). In consequence, for the urinary $\left[{ }^{14} \mathrm{~N}^{15} \mathrm{~N}\right]$

Table 1. Comparison of hay-grass pellets $(\mathrm{HG})$ and concentrateforage (CF) diets for $\mathrm{N}$ digestibility and balance variables*

(Mean values for four sheep)

\begin{tabular}{|c|c|c|c|c|}
\hline & \multicolumn{2}{|c|}{ Diet } & \multicolumn{2}{|c|}{ One-way ANOVA $†$} \\
\hline & $H G$ & $\mathrm{CF}$ & SED & $P$ \\
\hline \multicolumn{5}{|l|}{ Balance variables } \\
\hline$N$ intake (g N/d) & $14 \cdot 30$ & $17 \cdot 14$ & 0.563 & 0.015 \\
\hline$N$ faeces $(\mathrm{g} \mathrm{N} / \mathrm{d})$ & 6.78 & $5 \cdot 62$ & 1.013 & NS \\
\hline $\mathrm{N}$ urine $(\mathrm{g} \mathrm{N} / \mathrm{d})$ & $6 \cdot 24$ & 8.55 & 0.861 & 0.075 \\
\hline Urine urea-N (g N/d) & 3.42 & $5 \cdot 62$ & 0.964 & NS \\
\hline Urea-N/urine-N & 0.56 & 0.64 & 0.042 & NS \\
\hline $\mathrm{N}$ retention $(\mathrm{g} \mathrm{N} / \mathrm{d})$ & 1.27 & $2 \cdot 98$ & 0.756 & NS \\
\hline N digestibility (\%) & $52 \cdot 6$ & $66 \cdot 5$ & $7 \cdot 07$ & NS \\
\hline Plasma urea-N (mM) & $1 \cdot 70$ & 2.47 & 0.223 & 0.026 \\
\hline
\end{tabular}

* For details of composition of diets see p. 460 .

$\dagger$ Animals treated as blocks, 3 residual degrees of freedom.
Table 2. Comparison of hay-grass pellets $(\mathrm{HG})$ and concentrateforage (CF) diets for urea-N kinetics based on $\left[{ }^{15} N^{15} N\right]$ urea infusions for $4 d^{*}$

(Mean values for four sheep)

\begin{tabular}{|c|c|c|c|c|}
\hline & \multicolumn{2}{|c|}{ Diet } & \multicolumn{2}{|c|}{ One-way ANOVA } \\
\hline & $H G$ & $\mathrm{CF}$ & SED & $P$ \\
\hline \multicolumn{5}{|l|}{ Urea kinetic variables (g urea-N/d) } \\
\hline Production (UER) & 11.07 & $16 \cdot 30$ & 0.923 & 0.011 \\
\hline Entry to GIT (GER) & 7.67 & 9.91 & 0.816 & 0.071 \\
\hline Return to ornithine cycle (ROC) & 3.26 & 5.07 & 0.495 & 0.036 \\
\hline Loss to faeces (UFE) & 0.54 & 0.33 & 0.032 & 0.007 \\
\hline Re-use for anabolism (UUA) & 3.87 & 4.51 & 0.559 & NS \\
\hline \multicolumn{5}{|l|}{ Fractional transfers } \\
\hline UER to urine $(u)$ & 0.305 & 50.390 & 0.026 & 0.046 \\
\hline UER to GIT $(\mathrm{I}-\mathrm{u})$ & 0.695 & 50.610 & 0.026 & 0.046 \\
\hline GER to ROC $(r)$ & 0.424 & 40.513 & $3 \quad 0.272$ & 0.047 \\
\hline GER to faeces (f) & 0.071 & 10.033 & 30.007 & 0.013 \\
\hline GER to UUA (a) & 0.505 & 50.454 & $4 \quad 0.024$ & NS \\
\hline
\end{tabular}

UER, urea-N entry rate; GER, gastrointestinal entry rate; ROC, return to ornithine cycle; UFE, loss to faeces; UUA, urea-N utilised for anabolism; GIT, gastrointestinal tract.

* For details of composition of diets see p. 460.

$\dagger$ Animals treated as blocks, 3 residual degrees of freedom.

urea: $\left[{ }^{15} \mathrm{~N}^{15} \mathrm{~N}\right]$ urea ratios there was a significant effect of time $(P<0.001)$ that disappeared on days 3 and 4 (Fig. 4). There was no effect of diet and the final ratios averaged 0.45 . Mean daily plasma urea concentrations were greater $(P=0.026)$ for diet CF (Table 1).

Daily urea-N production and GER were consistent and, on each of the last $3 \mathrm{~d}$ of infusion, were within $5 \%$ of the mean value. Urea-N entry rates $(\mathrm{g} \mathrm{N} / \mathrm{d})$, calculated as the average of days 2 to 4 inclusive, were greater for the $\mathrm{CF}$ diet $(+47 \%, P=0.011$; Table 2$)$, as was urea entry into the GIT, both in absolute terms $(+29 \%, P=0.07)$ and as the fraction $(1-\mathrm{u})$ of UER $(+28 \% ; P=0.046)$. There was a corresponding decrease in the fraction (u) of urea-N production that was eliminated in the urine $(-12 \%, P=$ 0.046). Urea-N recycled to the ornithine cycle (ROC), quantified over the last $2 \mathrm{~d}$ of infusion, was greater for the $\mathrm{CF}$ ration both in absolute amounts $(+55 \%, P=0.036)$ and as a proportion (r) of GIT entry $(+21 \%, P=0.047)$. Faecal ${ }^{15} \mathrm{~N}$ enrichments increased daily (Fig. 5), with a similar pattern for faecal total ${ }^{15} \mathrm{~N}$ excretion (data not shown). Faecal ${ }^{15} \mathrm{~N}$ enrichments (atom percent excess) were 6-11-fold lower than those of urinary urea. Although more urea-N was apparently lost in faeces (UFE) on the HG ration $(+63 \%, P<0.01)$, comprising a larger proportion (f) of GER $(+215 \%, P<0.05)$, the amounts were numerically small, less than $5 \%$ of UER. Despite these differences between diets in partition of GER to catabolic fates (i.e. to ROC and UFE), the amounts of urea-N apparently reutilised for anabolic purposes (i.e. that did not enter the catabolic pathways within the time scale of infusion) were similar. Thus, most of the higher GER on ration $\mathrm{CF}$ was directed towards catabolic fates.

\section{Discussion}

Urea entry into the digestive tract has been long recognised as a major mechanism in ruminants through which 

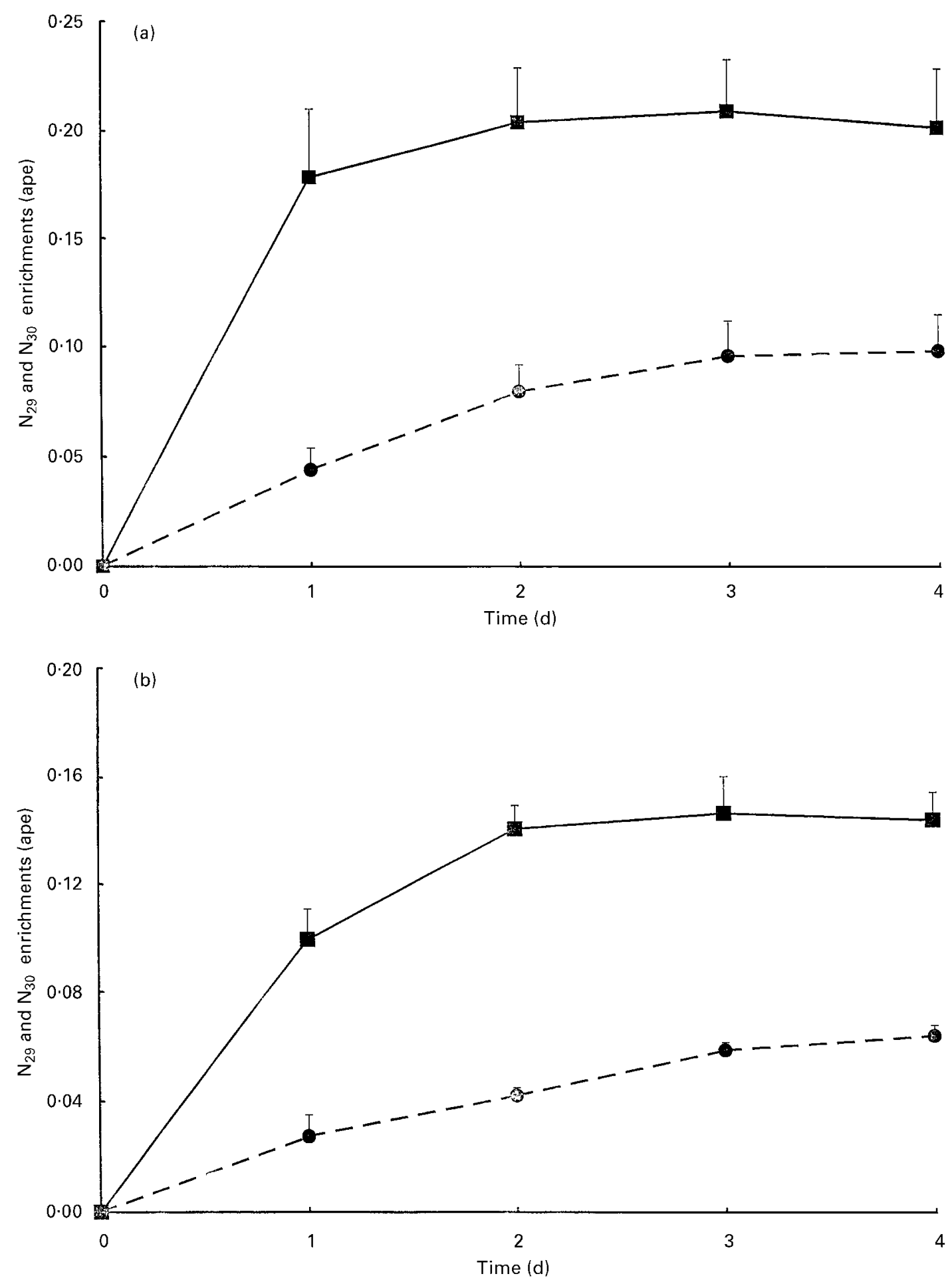

Fig. 3. Enrichments of $\left[{ }^{15} \mathrm{~N}^{15} \mathrm{~N}\right]$ urea $\left(\mathrm{N}_{30} ;(\mathbf{\square}-\mathbf{-})\right)$ and $\left[{ }^{14} \mathrm{~N}^{15} \mathrm{~N}\right]$ urea $\left(\mathrm{N}_{29} ;(---\bullet)\right)$ in urine during a 4 d intravascular infusion of $\left[{ }^{15} \mathrm{~N}^{15} \mathrm{~N}\right]$ urea for (a) a hay-grass pellet diet and (b) a concentrate-forage ration. For details of composition of diets see p. 460 . Values are means for four sheep with standard errors represented by vertical bars. ape, atom percent excess.

'salvage' of $\mathrm{N}$ produced from $\mathrm{NH}_{3}$ and amino acid metabolism is achieved. In many situations, urea-N production equals or exceeds the amount of $\mathrm{N}$ apparently digested (e.g. Reynolds et al. 1991, Sarreseca et al. 1998; present study), i.e. the animal would be in permanent negative $\mathrm{N}$ balance unless mechanisms existed to recycle and recover N. Many studies have examined the amount of urea-N that enters the digestive tract and the factors which regulate such entry (e.g. Egan et al. 1986). The methods used have included the relatively non-invasive urea entry rate approach coupled with urinary urea collection (e.g. Bunting et al. 1987), as well as the surgically-invasive 


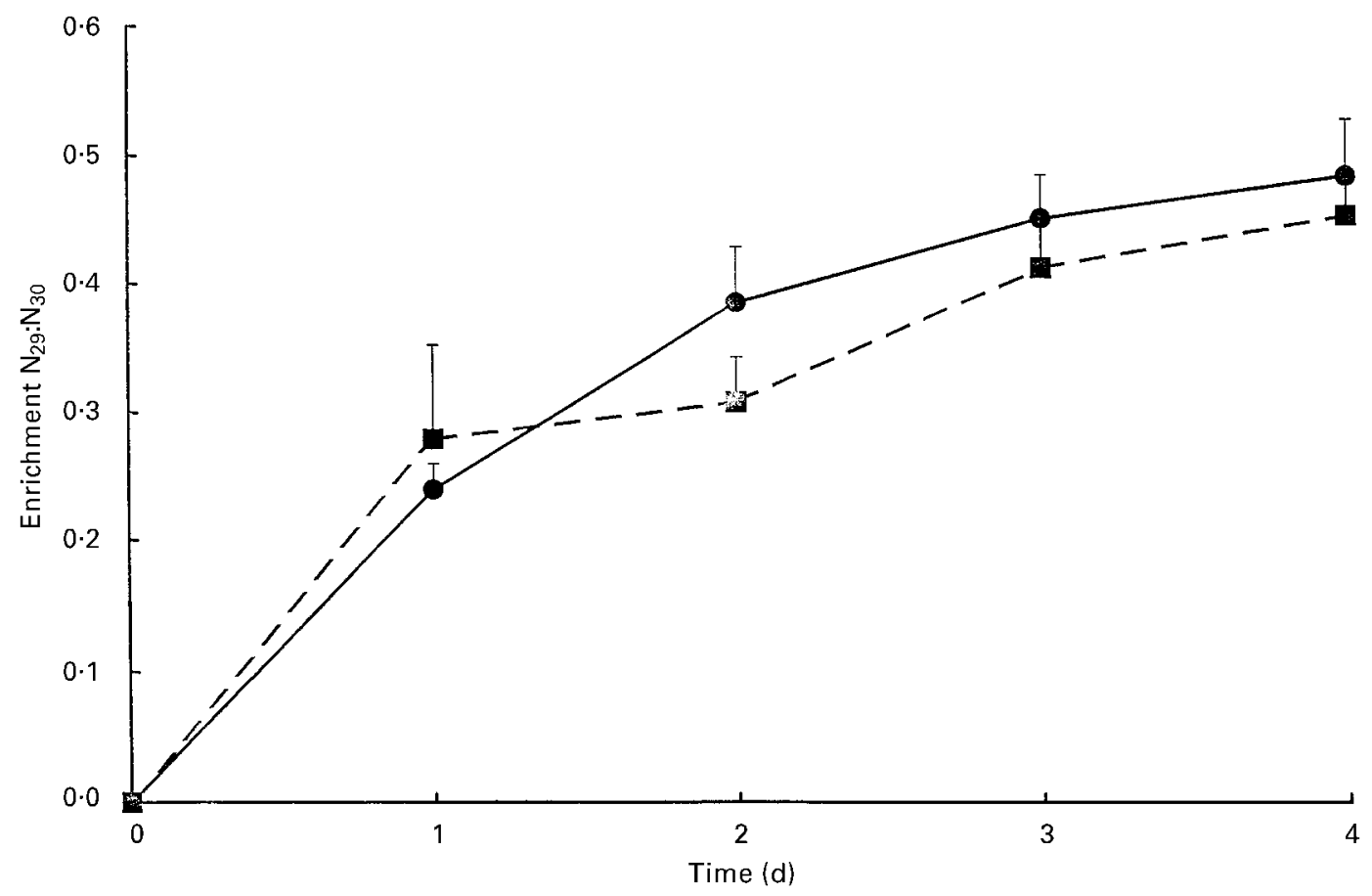

Fig. 4. Urinary $\left[{ }^{14} N^{15} N\right]$ urea: $\left[{ }^{15} N^{15} N\right]$ urea enrichment ratios $\left(N_{29}: N_{30}\right)$ during a 4 d intravascular infusion of $\left[{ }^{15} N^{15} N\right]$ urea for a hay-grass pellet

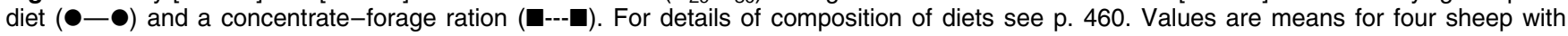
standard errors represented by vertical bars.

arterio-venous preparations across the liver and portaldrained viscera (e.g. Reynolds et al. 1991; Lobley et al. 1996; Whitt et al. 1996). The former technique is applicable to studies lasting for several days, while the latter methodology is suited for short-term measurements over a few hours. Both approaches are restricted in that the data obtained only describe entry to the GIT, not the fate of the urea-N thereafter. Determination of the latter requires

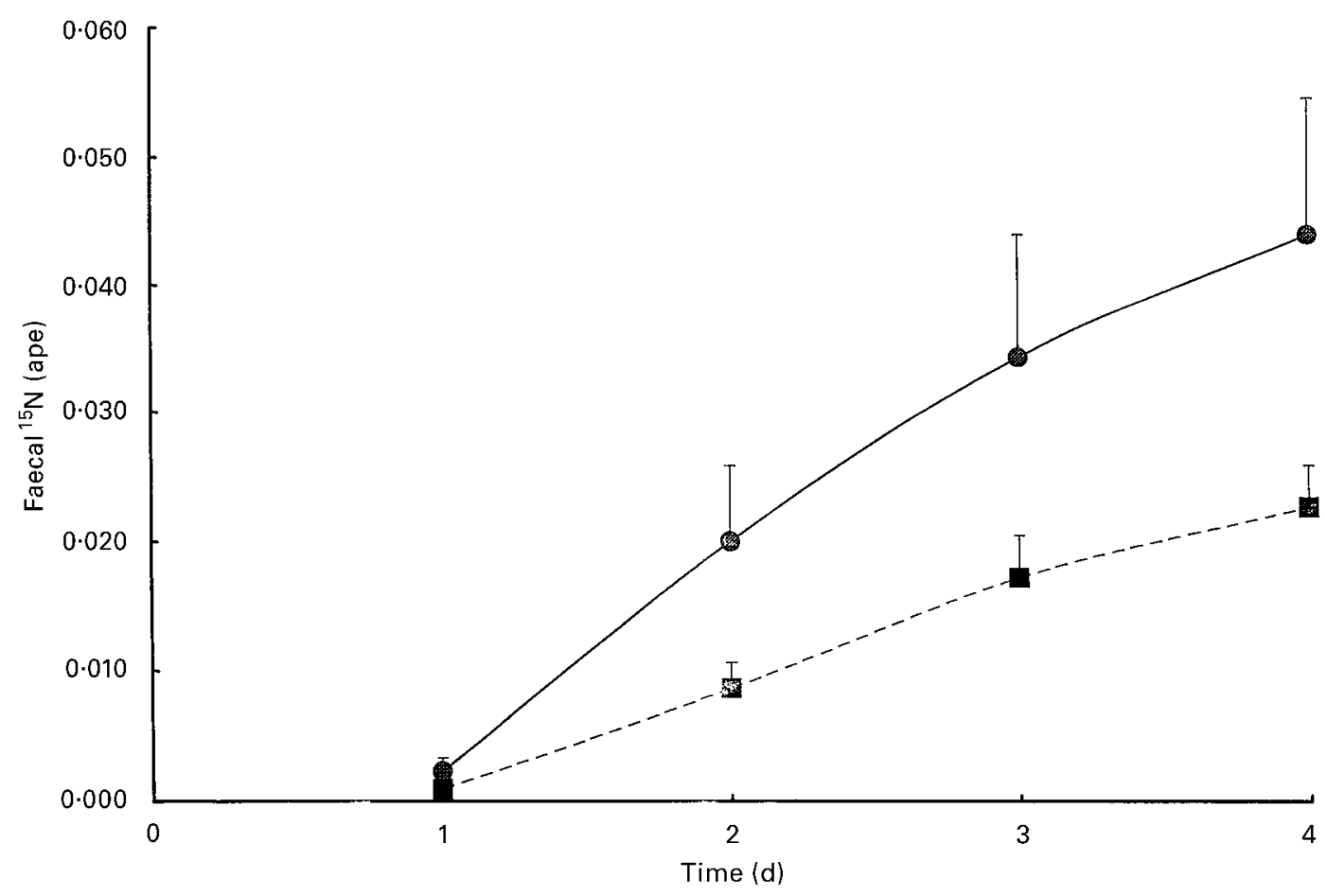

Fig. 5. Faecal ${ }^{15} \mathrm{~N}$ enrichments during a $4 \mathrm{~d}$ intravascular infusion of $\left[{ }^{15} \mathrm{~N}^{15} \mathrm{~N}\right]$ urea for a hay-grass pellet diet $(\bullet-\bullet)$ and a concentrate-forage ration (ם--- $\mathbf{\square})$. For details of composition of diets see p. 460 . Values are means for four sheep with standard errors represented by vertical bars. 
use of isotopic labels, usually ${ }^{15} \mathrm{~N}$, although radioactive ${ }^{13} \mathrm{~N}$ has been used in rodents (e.g. Cooper et al. 1987). Indeed, elegant models have been constructed based on ${ }^{15} \mathrm{~N}$ metabolite transfers to and from the compartments of the digestive tract (Siddons et al. 1985). These have yielded very detailed information on $\mathrm{N}$ transfers but have required complex methodology and modelling expertise. The approach described in the present paper is much simpler and provides estimates of the catabolic and anabolic fates of urea-N. The data are more limited in that the GIT is considered as a single compartment, rather than separation into the major areas (rumen, small intestine, hind gut etc.) as is possible with the complex alternative approaches (Siddons et al. 1985).

The current study extends the theoretical, technical and biological information available from the previous application of the technique to ruminants (Sarraseca et al. 1998). In theoretical terms, the previous equations were applicable only to continuous infusion and steady-state conditions. For certain experiments, in both large and small animals, single (pulse) injection followed by complete collection of urine over subsequent days may be preferred. The new equations cover both single and continuous dose protocols. Furthermore, the previous comparison of single $v$. multiple entry of urea-N into the GIT stated that the former over-estimated ROC (Sarraseca et al. 1998), whereas actually an underestimation is obtained. The equations for multiple entry, the preferred model, were correct, however.

On the technical front, the loss of urea ${ }^{15} \mathrm{~N}$ in the faecal biomass has now been included. The rate of labelling of the GIT digesta clearly had not attained constant enrichments within $4 \mathrm{~d}$ of infusion. Because the GIT is treated as a single compartment, the data do not allow resolution of whether the faecal ${ }^{15} \mathrm{~N}$ represents transfers through the whole GIT or reflects primarily movement of urea into the hind gut. In dairy cows, ${ }^{15} \mathrm{~N}$ enrichment of faeces was detected within $4 \mathrm{~h}$ of the start of intravascular $\left[{ }^{15} \mathrm{~N}\right]$ urea infusion, affirming passage of urea into the large intestine and caecum (Al-Dehneh et al. 1997). The same report also observed that faecal enrichments did not attain plateau during the $72 \mathrm{~h}$ infusion.

A second technical issue relates to the length of time that the infusions need to be continued to obtain quasi-steady state for $\left[{ }^{15} \mathrm{~N}^{15} \mathrm{~N}\right]$ urea and $\left[{ }^{14} \mathrm{~N}^{15} \mathrm{~N}\right]$ urea enrichments. The model predicts that at least three GIT entries and associated ROC can occur before the probability of elimination of urea-N in the urine approaches unity. Such movements account for the additional $12-24 \mathrm{~h}$ needed after $\left[{ }^{15} \mathrm{~N}^{15} \mathrm{~N}\right]$ urea plateau before that for $\left[{ }^{14} \mathrm{~N}^{15} \mathrm{~N}\right]$ urea was obtained. While time scales of 52-56 h (see also Sarraseca et al. 1998) appear appropriate for sheep, at least under the experimental conditions employed, they may not be suitable in other circumstances. For example, Al-Dehneh et al. (1997) found that none of the fractions examined (e.g. urinary- $\mathrm{N}$, faecal-N, digesta-N, bacterial-N) attained constant enrichment after $72 \mathrm{~h}$ of $\left[{ }^{15} \mathrm{~N}\right]$ urea infusion in dairy cows. Unfortunately, they did not use a procedure specific for urinary urea analysis, nor did they resolve $\left[{ }^{15} \mathrm{~N}^{15} \mathrm{~N}\right]$ and $\left[{ }^{14} \mathrm{~N}^{15} \mathrm{~N}\right]$ species. The half-life of the body urea pool in lactating cows is of similar magnitude to sheep $(3.4-5 \cdot 2 \mathrm{~h}$; from Reynolds et al. 1988) and so, in theory, should have achieved a constant enrichment within 20-26 h.
The two diets were not intended to be isonitrogenous. Indeed, even if rations are matched for apparent digestible $\mathrm{N}$, the ratios of the main $\mathrm{N}$ end-products (amino acids and $\mathrm{NH}_{3}$ ) may still differ. The differences between $\mathrm{CF}$ and $\mathrm{HG}$ in daily $\mathrm{N}$ intake (3 g) and digestible $\mathrm{N}(4 \mathrm{~g})$ were still less than the increase in urea-N production $(5 \mathrm{~g})$. The 'extra' $\mathrm{N}$ required for UER arose from the additional $2.2 \mathrm{~g}$ urea-N which entered the GIT, the majority of which $(1.8 \mathrm{~g})$ was returned to the ornithine cycle. Many factors influence urea entry to the GIT, in both absolute terms and as a proportion of urea production (for reviews see Harmeyer \& Martens, 1980; Kennedy \& Milligan, 1980; Egan et al. 1986). Indeed, the proportion of UER which enters the GIT can vary between 10-95\% and is negatively correlated with intake of crude protein (Harmeyer \& Martens, 1980). In the present study, the fraction of urea production that entered the GIT was also greater for the HG diet with the lower crude protein $(\mathrm{N} \times 6.25)$ content. The GER:UER ratio obtained with the isotopic technique $(0 \cdot 62-0 \cdot 73$, Sarraseca et al. 1998; 0.61-0.70, current study) are greater than those derived directly from arterio-venous studies with similar sheep and diets (c.f. 0.43-0.56, Lobley et al. 1995, 1996). The latter technique will provide an underestimate because urea-N inflows to the GIT via saliva (Harmeyer \& Martens, 1980; Várady et al. 1979) and other biological fluids (e.g. bile, pancreatic secretions) are not measured. These inflows will be included in the isotopic transfers.

The major advantage of the isotopic approach is the ability to partition the fate of GER between anabolic and catabolic fates. In the current study, 45-50\% of GER was diverted to anabolic (or, more correctly, noncatabolic) routes. A limit of utilisation may already have been achieved, in that most of the additional $\mathrm{N}$ returned to the GIT with the CF ration, was not used for productive purposes. As GER was equivalent to 53-58 \% of $\mathrm{N}$ intake (and 86-102\% of apparent digestible $\mathrm{N}$ ) for the two diets, the ability to utilise the extra $\mathrm{N}$ sources may be restricted by other factors, e.g. energy supply (Kennedy \& Milligan, 1980). The capacity for protein anabolism also may be limited in sheep of the age and weight used. The simple isotopic method employed here has the disadvantage that the GIT is treated as a single compartment whereas, in practice, only urea-N that enters the rumen (e.g. Egan et al. 1986) or the small intestine (Torrallardona et al. 1996) will provide substrate for anabolic metabolites absorbed by the animal. Thus, the potential for GER may be overestimated, particularly if substantial quantities of urea-N enter the hind gut. In practice, however, this latter contribution is probably relatively small under most circumstances. For example, with cattle offered concentrates, approximately $65-76 \%$ of the urea-N transfer to the GIT enters the fore-stomachs (Reynolds \& Huntington, 1988; Huntington, 1989). In contrast, the amount of urea- $\mathrm{N}$ which enters the caecum and colon of sheep is low (approximately $1 \mathrm{~g} \mathrm{~N} / \mathrm{d}$; Dixon $\&$ Nolan, 1986), and if comparable inflows existed in the current study, then this may contribute to the $0 \cdot 3-0.5 \mathrm{~g}$ of urea-N lost via the faeces. Although claims have been made that absorption of essential amino acids can occur from the large bowel in humans subjects (Jackson, 1995), this remains controversial (El-Khoury et al. 1996). 
Formation of $\left[{ }^{14} \mathrm{~N}^{15} \mathrm{~N}\right]$ urea arises primarily from absorbed ${ }^{15} \mathrm{NH}_{3}$, although it may also be produced following catabolism of $\left[{ }^{15} \mathrm{~N}\right]$ amino and nucleic acids. Between 40-50 \% of GER was reconverted to urea-N and this can be a substantial proportion of total $\mathrm{NH}_{3}$ absorption across the GIT. For example, from arterio-venous studies in cattle and sheep, urea-N entry into the GIT is numerically 27-84\% of $\mathrm{NH}_{3}$ absorption across the portal-drained viscera (e.g. from Huntington et al. 1989, 1996; Reynolds et al. 1991; Whitt et al. 1996; Lobley et al. 1998). In these reports, if the fraction returned to the ornithine cycle were similar to the current studies, then as much as $40 \%$ of $\mathrm{NH}_{3}$ absorption may arise from urea recycled to the digestive tract.

The isotopic approach used obtains the anabolic fate of urea-N by difference. Anabolism within the rumen, and probably the GIT lumen through to the terminal ileum, is assumed to be predominantly as transfer of liberated $\mathrm{NH}_{3}$ into the amino acids of microbial protein, although other $\mathrm{N}$ metabolites of the microflora may also be formed. Anabolism from $\mathrm{NH}_{3}$ within the body may arise from either amination or transamination reactions. The first of these two processes represents potential anabolism (conversion of oxo-acid to amino acid) while the latter does not, in that only exchange of ${ }^{14} \mathrm{~N}$ and ${ }^{15} \mathrm{~N}$ occurs, i.e. there is no net gain of $\mathrm{N}$ by the system. Thus 'anabolism', as assessed by the isotopic approach, may be overestimated by the extent of any transamination within tissues that involves ${ }^{15} \mathrm{~N}$ movements.

The refinements introduced within this study provide information on the time-scales necessary for pseudoplateaux to be obtained for the two labelled forms of urea and provide calculations applicable to both continuous infusion and single dose procedures. For the latter, complete collection of the urine is necessary over several days (probably $72 \mathrm{~h}$ or more). In contrast, for continuous infusions, the ${ }^{15} \mathrm{~N}$ enrichments can be obtained on 'spot' samples, although measurement of daily urea output in urine is also required. The two non-isonitrogenous rations employed yielded differences in both rate of urea production and entry to the GIT but the amounts of the latter available for anabolic purposes were similar. Instead, for the higher $\mathrm{N}$ intake of the CF ration, more of the urea- $\mathrm{N}$ was returned to the ornithine cycle and thus increased flow through the catabolic pathways. Although requiring a degree of technical expertise, the method yields information from a single tracer that hitherto has required the use of two isotopes of urea (e.g. Bunting et al. 1987). The method also allows a simple means to obtain data that otherwise requires surgically invasive procedures across the splanchnic tissues and for which considerable analytical precision needs to be employed. It is envisaged that the technique may be used for simple evaluation of urea kinetics in response to a number of nutritional and physiological events, prior to using more elaborate and invasive approaches.

\section{Acknowledgement}

This study was funded as part of the core grant to the Rowett Research Institute by the Scottish Executive Rural Affairs Department.

\section{References}

Al-Dehneh A, Huber JT, Wanderley R, Theurer CB, Pessarakli M \& DeYoung D (1997) Incorporation of recycled urea-N into ruminal bacteria flowing to the small intestine of dairy cows fed a high-grain or high-forage diet. Animal Feed Science Technology 68, 327-338.

Bunting LD, Boling JA, MacKown CT \& Muntifering RB (1987) Effect of dietary protein level on nitrogen metabolism in lambs: studies using ${ }^{15} \mathrm{~N}$-nitrogen. Journal of Animal Science 64, 855867.

Cooper AJL, Nieves E, Coleman AE, Filc-De Ricco S \& Gelbard AS (1987) Short term metabolic fate of $\left[{ }^{13} \mathrm{~N}\right]$ ammonia in rat liver in vivo. Journal of Biological Chemistry 262, 1073-1080.

Dixon RM \& Nolan JV (1986) Nitrogen and carbon flows between the caecum, blood and rumen in sheep given chopped lucerne (Medicago sativa) hay. British Journal of Nutrition 55, 313-332.

Egan AR, Boda K \& Varady J (1986) Regulation of nitrogen metabolism and recycling. In Control of Digestion and Metabolism in Ruminants, pp. 386-402 [LP Milligan, WL Grovum and A Dobson, editors]. Englewood Cliffs, NJ: Prentice-Hall.

El-Khoury AE, Ajami AM, Fukagawa NK, Chapman TE \& Young VR (1996) Diurnal pattern of the interrelationships among leucine oxidation, urea production and hydrolysis in humans. American Journal of Clinical Physiology 271, E563E573.

Harmeyer J \& Martens H (1980) Aspects of urea metabolism in ruminants with reference to the goat. Journal of Dairy Science 63, $1707-1728$

Huntington GB (1989) Hepatic urea synthesis and site and rate of urea removal from blood of beef steers fed alfalfa hay or a high concentrate diet. Canadian Journal of Animal Science 69, 215223.

Huntington GB, Zetina EJ, Whitt JM \& Potts W (1996) Effects of dietary concentrate level on nutrient absorption, liver metabolism, and urea kinetics of beef steers fed isonitrogenous and isoenergetic diets. Journal of Animal Science 74, 908-916.

Jackson AA (1995) Salvage of urea-nitrogen and protein requirements. Proceedings of the Nutrition Society 54, 535547.

Jackson AA, Picou D \& Landman JP (1984) The non-invasive measurement of urea kinetics in normal man by a constant infusion of ${ }^{15} \mathrm{~N}^{15} \mathrm{~N}$-urea. Clinical Nutrition 38C, 339-354.

Jackson AA, Danielsen MS \& Boyes S (1993) A non-invasive method for measuring urea kinetics with a single dose of ${ }^{15} \mathrm{~N}^{15} \mathrm{~N}$-urea in free-living humans. Journal of Nutrition 123, 2129-2136.

Kennedy PM \& Milligan LP (1980) The degradation and utilization of endogenous urea in the gastrointestinal tract of ruminants: a review. Canadian Journal of Animal Science $\mathbf{6 0}$, 205-221.

Lobley GE, Bremner DM, Nieto R, Obitsu T, Hotston Moore A \& Brown DS (1998) Transfers of $\mathrm{N}$ metabolites across the ovine liver in response to short-term infusions of an amino acid mixture into the mesenteric vein. British Journal of Nutrition 80, 371-379.

Lobley GE, Connell A, Lomax MA, Brown DS, Milne E, Calder AG \& Farningham DAH (1995) Hepatic detoxification of ammonia in the ovine liver: possible consequences for amino acid catabolism. British Journal of Nutrition 73, 667-685.

Lobley GE, Weijs PJM, Connell A, Calder AG, Brown DS \& Milne E (1996) The fate of absorbed and exogenous ammonia as influenced by forage or forage-concentrate diets in growing sheep. British Journal of Nutrition 76, 231-248.

Reynolds CK \& Huntington GB (1988) Partition of portal-drained 
visceral net flux in beef steers. 1. Blood flow and net flux of oxygen, glucose and nitrogenous compounds across stomach and post-stomach tissues. British Journal of Nutrition 60, 539551.

Reynolds CK, Huntington GB, Tyrrell HF \& Reynolds PJ (1988) Net-portal-drained visceral and hepatic metabolism of glucose, L-lactate and nitrogenous compounds in lactating Holstein cows. Journal of Dairy Science 71, 1803-1812.

Reynolds CK, Tyrrell HF \& Reynolds PJ (1991) Effects of diet forage-to-concentrate ratio and intake on energy metabolism in growing beef heifers: net nutrient metabolism by visceral tissues. Journal of Nutrition 121, 1004-1015.

Sarraseca A, Milne E, Metcalf MJ \& Lobley GE (1998) Urea recycling in sheep: effects of intake. British Journal of Nutrition 79, 79-88.

Siddons RC, Nolan JV, Beever DE \& MacRae JC (1985) Nitrogen digestion and metabolism in sheep consuming diets containing contrasting forms and levels of N. British Journal of Nutrition 54, 175-187.

Torrallardona D, Harris CI, Coates ME \& Fuller MF (1996) Microbial amino acid synthesis and utilization in rats. 1. Incorporation of ${ }^{15} \mathrm{~N}$ from ${ }^{15} \mathrm{NH}_{4} \mathrm{Cl}$ into lysine in the tissues of germ-free and conventional rats. British Journal of Nutrition 76, 689-700.

Várady J, Tashenov KT, Boda K, Fejes J \& Kosta K (1979) Endogenous urea secretion into the sheep gastrointestinal tract. Physiologia Bohemoslovaca 28, 551-559.

Whitt J, Huntington G, Zetina E, Casse E, Taniguchi K \& Potts W (1996) Plasma flow and net nutrient flux across gut and liver of cattle fed twice daily. Journal of Animal Science 74, 24502461.

Wolfe RR (1981) Measurement of urea kinetics in vivo by means of a constant tracer infusion of di- ${ }^{15} \mathrm{~N}$-urea. American Journal of Physiology 240, E428-E434.

\section{Appendix}

The derivation of the model should be considered together with the schematic isotopic flows shown in Fig. 2. The various mass flows through the body urea pool can be represented as follows:

$$
\mathrm{UER}=\mathrm{UUE}+\mathrm{GER},
$$

$$
\mathrm{UUE}=\mathrm{u} \text { UER, }
$$

and

$$
\operatorname{GER}=(1-u) \mathrm{UER}
$$

The corresponding flows through the GIT are:

$$
\begin{gathered}
\text { GER }=\mathrm{UUA}+\mathrm{UFE}+\mathrm{ROC}, \\
\mathrm{UUA}=\mathrm{a} \text { GER }, \\
\mathrm{UFE}=\mathrm{f} \text { GER },
\end{gathered}
$$

and

$$
\mathrm{ROC}=\mathrm{rGER},
$$

and where

$$
\mathrm{a}+\mathrm{f}+\mathrm{r}=1 \text {. }
$$

These, and the following equations, extend, correct and clarify earlier approaches (Jackson et al. 1984, 1993; Sarraseca et al. 1998) and are applicable to both continuous infusion (steady state) and single injection procedures.

Urea $\left[{ }^{15} \mathrm{~N}^{15} \mathrm{~N}\right]$ and urea $\left[{ }^{14} \mathrm{~N}^{15} \mathrm{~N}\right]$ enrichments in the blood (or plasma) are considered identical to those in the urine. Urea ${ }^{15} \mathrm{~N}$ transfers to body pools (e.g. GIT, urine, faeces, tissue protein) can be partitioned between those derived from $\left[{ }^{15} \mathrm{~N}^{15} \mathrm{~N}\right]$ urea, given the subscript 30 (molecular mass of $\mathrm{N}_{2}$ gas liberated and analysed), and those from $\left[{ }^{14} \mathrm{~N}^{15} \mathrm{~N}\right]$ urea, given the subscript 29 . Because labelled and unlabelled urea- $\mathrm{N}$ are assumed to be indistinguishable by the body, then the labelled $\mathrm{N}$ flows through the urea pools (see Fig. 2) can, by analogous reasoning to that above, be expressed as: (1) for body urea labelled N:

$$
\mathrm{D}_{30}=\mathrm{UUE}_{30}+\mathrm{GER}_{30} .
$$

For continuous infusion approaches, this equation has units mass/time. For a single dose study, $\mathrm{D}_{30}$ is converted from mass to mass/time, where time is the period over which full collection of urinary urea- $\mathrm{N}$ and faecal- $\mathrm{N}$ is made.

Furthermore:

$$
\mathrm{ROC}^{*}=\mathrm{UUE}_{29}+\mathrm{GER}_{29},
$$

where $*$ refers to labelled $\mathrm{N}$ (sourced from either $\left[{ }^{15} \mathrm{~N}^{15} \mathrm{~N}\right]$ urea or $\left[{ }^{14} \mathrm{~N}^{15} \mathrm{~N}\right]$ urea entry to the GIT).

Then:

$$
\begin{gathered}
\mathrm{UUE}_{30}=\mathrm{u} \mathrm{D}_{30}, \\
\mathrm{UUE}_{29}=\mathrm{u} \mathrm{ROC}^{*}, \\
\mathrm{GER}_{30}=(1-\mathrm{u}) \mathrm{D}_{30},
\end{gathered}
$$

and

$$
\mathrm{GER}_{29}=(1-\mathrm{u}) \mathrm{ROC}^{*} ;
$$

(2) for GIT labelled urea-N:

$$
\begin{gathered}
\mathrm{GER}^{*}=\mathrm{GER}_{29}+\mathrm{GER}_{30}, \\
\mathrm{ROC}^{*}=\mathrm{rGER}^{*}, \\
\mathrm{UUA}^{*}=\mathrm{a} \mathrm{GER}^{*},
\end{gathered}
$$

and

$$
\mathrm{UFE}^{*}=\mathrm{fGER}^{*}
$$

It should be noted that $\mathrm{GER}_{30}$ is a once-only event as any $\left[{ }^{15} \mathrm{~N}^{15} \mathrm{~N}\right]$ urea which enters the GIT is converted to ${ }^{15} \mathrm{~N}$ products and the probability that these will be reformed to $\left[{ }^{15} \mathrm{~N}^{15} \mathrm{~N}\right]$ urea is negligible. In contrast, from GIT hydrolysis of $\left[{ }^{14} \mathrm{~N}^{15} \mathrm{~N}\right]$ urea, the ${ }^{15} \mathrm{~N}$ released can combine with ${ }^{14} \mathrm{~N}$ in the ornithine cycle to reform $\left[{ }^{14} \mathrm{~N}^{15} \mathrm{~N}\right]$ urea. Therefore, in theory, $\mathrm{a}^{15} \mathrm{~N}$ atom can enter the GIT an infinite number of times. The mathematical derivation of earlier models (Jackson et al. 1984, 1993) assumed only a single GIT 
entry of $\left[{ }^{14} \mathrm{~N}^{15} \mathrm{~N}\right]$ urea, and this leads to an underestimate of r (i.e. ROC) and an overestimate of urea-N available for anabolism.

\section{Calculations}

Now, from (i):

$$
\mathrm{GER}=\mathrm{UER}-\mathrm{UUE},
$$

where UER is calculated from the dilution of $\left[{ }^{15} \mathrm{~N}^{15} \mathrm{~N}\right]$ urea in urine (see equation (1) or (8)). From (ii):

$$
\mathrm{u}=\frac{\mathrm{UUE}}{\mathrm{UER}},
$$

from (viii):

$$
\mathrm{ROC}^{*}=\frac{\mathrm{UUE}_{29}}{\mathrm{u}},
$$

while from (ix) and (x):

$$
\mathrm{GER}^{*}=(1-\mathrm{u})\left(\mathrm{D}_{30}+\mathrm{ROC}^{*}\right) .
$$

Alternatively, GER ${ }^{*}$ can be calculated as:

$$
\mathrm{GER}^{*}=\mathrm{GER} \frac{\mathrm{UUE}^{*}}{\mathrm{UUE}},
$$

where (UUE $\left.{ }^{*} / \mathrm{UUE}\right)$ is the total enrichment of $\left[{ }^{15} \mathrm{~N}\right]$ urea (atom percent excess/100) in the urine. From (xi), (xii) and (v) respectively:

$$
\begin{gathered}
\mathrm{r}=\mathrm{ROC}^{*} / \mathrm{GER}^{*} \\
\mathrm{f}=\mathrm{UFE}^{*} / \mathrm{GER}^{*} \\
\mathrm{a}=1-\mathrm{f}-\mathrm{r} .
\end{gathered}
$$

Using values for r, f, a and GER from (xvii), (xviii), (xix) and (xiii) respectively, ROC, UFE and UUA can be calculated.

Equations (2), (5) and (6) are given in (xiv), (xix) and (xiii) respectively. Substitution of (xvi) in (xvii), and multiplying both numerator and denominator by $\mathrm{u}$, and substituting (vii) and (viii) gives equation (3). To obtain equation (4), (xvi) is rewritten as $\mathrm{GER}^{*}=(1-$ $\mathrm{u})\left(\mathrm{UUE}_{29}+\mathrm{UUE}_{30}\right) / \mathrm{u}$. Substituting in (xviii) gives equation (4). Finally, equation (7) is obtained from substituting (iii) and equation (3) in (iv).

These equations hold for multiple (infinite) recycling of $\left[{ }^{14} \mathrm{~N}^{15} \mathrm{~N}\right]$ urea through the GIT. If only a single entry of $\left[{ }^{14} \mathrm{~N}^{15} \mathrm{~N}\right]$ urea through the GIT were allowed (Jackson et al. 1984, 1993) then:

$$
\mathrm{r}=\frac{\mathrm{UUE}_{29}}{(1-\mathrm{u}) \mathrm{D}_{30}}
$$

which is an underestimate of the true $r$. True $r$ is given by $\mathrm{r}=\mathrm{UUE}_{29} /\left((1-\mathrm{u})\left(\mathrm{UUE}_{29}+\mathrm{UUE}_{30}\right)\right)$ and obviously $\mathrm{D}_{30}>\left(\mathrm{UUE}_{29}+\mathrm{UUE}_{30}\right)$. Because UUE and UER are identical between the models then the single-entry approach leads to an overestimate of UUA. The earlier analysis (Sarraseca et al. 1998) predicted that the single entry model would overestimate $\mathrm{r}$ and ROC but there was an equation error that failed to allow for removal of recycled urea- $\mathrm{N}$ from the body into urine.

The practical approach adopted in this study involves 'correction' (subtraction) of the $\mathrm{UUE}_{29}$ data for the presence of $\left[{ }^{14} \mathrm{~N}^{15} \mathrm{~N}\right]$ present in the original dose (i.e. $\mathrm{D}_{29}$ ). An alternative strategy is not to make this adjustment but use appropriate modified equations for (vi), (viii) and (x). These become, respectively:

$$
\begin{gathered}
\mathrm{ROC}^{*}+\mathrm{D}_{29}=\mathrm{UUE}_{29}+\mathrm{GER}_{29}, \\
\mathrm{UUE}_{29}=\mathrm{u}\left(\mathrm{ROC}^{*}+\mathrm{D}_{29}\right),
\end{gathered}
$$

and

$$
\operatorname{GER}_{29}=(1-\mathrm{u})\left(\mathrm{ROC}^{*}+\mathrm{D}_{29}\right) .
$$

The calculations for ROC ${ }^{*}$ and GER ${ }^{*}$, given by equations $(\mathrm{xv})$ and (xvi), then become:

$$
\mathrm{ROC}^{*}=\frac{1}{\mathrm{u}}\left(\mathrm{UUE}_{29}-\mathrm{u} \mathrm{D}_{29}\right),
$$

and

$$
\mathrm{GER}^{*}=(1-\mathrm{u})\left(\mathrm{D}_{30}+\mathrm{D}_{29}+\mathrm{ROC}^{*}\right) .
$$

Equations (3) and (7) convert to:

$$
\mathrm{r}=\frac{\rho}{1-\mathrm{u}}-\frac{\mathrm{u}}{1-\mathrm{u}} \frac{\mathrm{D}_{29}}{\mathrm{UUE}_{29}+\mathrm{UUE}_{30}},
$$

and

$$
\text { ROC }=\left(1-u \frac{\mathrm{D}_{29}}{\mathrm{UUE}_{29}}\right) \rho \mathrm{UER} .
$$

Equations (1), (2) and (4)-(6) are not affected. 